\title{
Effects of Disodium Hydrogen Phosphate Addition and Heat Treatment on the Formation of Magnesium Silicate Hydrate Gel
}

Ảnh hưởng của dinatri hydro phốt phát và xử lý nhiệt đến sự hình thành gel magiê silicat hydrat

\author{
Phuong Thi Nguyet, Vu Thi Ngoc Minh* \\ Hanoi University of Science and Technology, Hanoi, Vietnam \\ *Email: minh.vuthingoc@hust.edu.vn
}

\begin{abstract}
The formation of magnesium silicate hydrate gel is crucial in preventing magnesia aggregates from over hydrated during the construction of refractory castables since the presence of magnesium hydroxide diminish the mechanical properties of the material. This work aimed to investigate the accelerating effects of sodium hydrogen phosphate and heat treatment on the formation of magnesium silicate hydrate gel. Time-dependent $\mathrm{pH}$ of magnesia - silica fume slurries with and without sodium hydrogen phosphate addition and heat treatment was measured to verify the dissolution of $\mathrm{MgO}$ and magnesium silicate hydrate formation. The effects of sodium hydrogen phosphate were differentiable only at small added amounts, whereas heat treatment at 50 degrees Celsius performed noticeable acceleration. This observation could be applicable in molding to maintain the stability of basic refractory castables.
\end{abstract}

Keywords: Magnesium silicate hydrate, gel, $\mathrm{pH}$.

Tóm tắt

Sự hình thành gel magiê silicat hydrat đóng vai trò thiết yếu trong việc ngăn cản cốt liệu magiê oxit bị hydrat hóa quá nhiều khi thi công bê tông chịu lửa kiềm tính vì sự hình thành magiê hydroxit làm suy giảm các tính chất cơ học của vật liệu này. Nghiên cứu này nhằm khảo sát tác dụng tăng tốc của natri hydro phốt phát và nhiệt lên việc tạo thành gel magiê silicat hydrat. Sự thay đổi độ $\mathrm{pH}$ theo thời gian của huyền phù magiê oxit silica fume được đo nhằm xác nhận sự hòa tan của magiê oxit cũng như sự hình thành magiê silicat hydrat. Các tác động của natri hydro photphat chỉ có thể phân biệt được khi dùng với hàm lượng nhỏ, trong khi đó việc gia nhiệt $0^{3} 50^{\circ} \mathrm{C}$ đã tàm tăng tốc đáng kể việc tạo thành gel. Quan sát này có thể được áp dụng trong đúc bê tông để duy trì sự ổn định của bê tông chịu lửa kiềm tính.

Từ khóa: Magiê silicat hydrat, gel, pH.

\section{Introduction}

Magnesium silicate hydrate (MSH) gel, the hydration product of the system $\mathrm{MgO}-\mathrm{SiO}_{2}-\mathrm{H}_{2} \mathrm{O}$, is of great interest in magnesia-based refractory castables, so-called basic refractory castables. In a moist environment, magnesia (MgO) dissolves, forming $\mathrm{Mg}(\mathrm{OH})_{2}$ precipitation, which then crystallizes to brucite $\left(\mathrm{MgO} \cdot \mathrm{H}_{2} \mathrm{O}\right)$. Since the density of brucite is lower than that of magnesia, this process results in volume expansion and crack formation in magnesia aggregates. Consequently, the durability of the castables is lowered [1,2]. Thus, it is necessary to prevent the approach of water to magnesia.

One solution in preventing hydration of magnesia is the use of microsilica. In a highly alkaline solution, microsilica is partially dissolved and forms MSH gel on the surface of magnesia grains. The gel acts as a barrier that prevents magnesia aggregates from further hydration [3]. Publications on the use of silica fume in magnesia-based refractory castable have focused mostly on additives that reduce the hydration rate of $\mathrm{MgO}[2,4,5]$, with or without the presence of calcium aluminate as the binder. The addition of silica fume is limited to a few percent due to the formation of low refractory phases of the system $\mathrm{CaO}-\mathrm{MgO}-\mathrm{SiO}_{2}[6]$.

Since refractory castables are constructed under non-standard conditions regarding humidity and temperature, environmental factors might affect the effectiveness of microsilica usage. In many cases, refractory castables are molded and rammed outdoor at up to $50{ }^{\circ} \mathrm{C}$ depending on the local climate. The present work aimed to evaluate the acceleration effects of $\mathrm{pH}$ and temperature on the formation of MSH gel in a solution containing fine-grain magnesia and microsilica. The crystallization of the gel during aging is also studied. 


\section{Experiment}

The MSH gel was prepared from a slurry of magnesium oxide ( $\geq 97$ wt.\% $\mathrm{MgO}$, ACS reagent, Merck), silica fume ( $>90.0$ wt.\% $\mathrm{SiO}_{2}$, Elkem Microsilica ( 940$)$ and distilled water. The solid content of the slurry was $10 \%$ for better dissolution of $\mathrm{MgO}$ so that the $\mathrm{pH}$ change of the slurry would be evident with or without a $\mathrm{pH}$ adjusting agent.[2] The molar ratio of $\mathrm{MgO}: \mathrm{SiO}_{2}$ was 3:4, similar to the molar ratio of these oxides in talc, a mineral well-known for its hydrophobic behavior. Disodium hydrogen phosphate dodecahydrate $(\geq \quad 99.0 \quad$ wt.\% $\mathrm{Na}_{2} \mathrm{HPO}_{4} \cdot 12 \mathrm{H}_{2} \mathrm{O}$, Xilong Chemical) was used to adjust the initial $\mathrm{pH}$ of the slurry. $\mathrm{Na}_{2} \mathrm{HPO}_{4}$ was selected other than strong bases such as $\mathrm{NaOH}$ because the use of disodium hydrogen phosphate would add phosphate hardening effects to the refractory castable upon heat treatment.[5,7] $\mathrm{pH}$ was measured at a 24-hour interval over a week. In another setting, the magnesia - silica fume slurry was stirred on a hot plate at $30^{\circ} \mathrm{C}, 40{ }^{\circ} \mathrm{C}$, and $50{ }^{\circ} \mathrm{C}$, and $\mathrm{pH}$ was measured at a 15-minute interval. These are temperatures that refractory castables often undergo during construction in reality. The slurry was then filtered and washed through a Whatman 1440-240 filter paper before thermogravimetric (TG/DTG) analysis and heat treatment. TG/DTG was performed in air at the heating rate of $10{ }^{\circ} \mathrm{C} /$ minute. Besides, the filtride was dried to constant weight at $105{ }^{\circ} \mathrm{C}$ before heated at different temperatures from $150{ }^{\circ} \mathrm{C}$ to $1000{ }^{\circ} \mathrm{C}$. The dwell time at each temperature was 30 minutes. The morphology of the dried filtride after heated at $350{ }^{\circ} \mathrm{C}$ for two hours was characterized by the X-ray diffraction (XRD) method with a 2-theta step size of 0.03 degrees.

\section{Results and Discussion}

\subsection{Effects of $\mathrm{Na}_{2} \mathrm{HPO}_{4}$ on the pH of Magnesia- Silica Fume Slurry.}

Without $\mathrm{Na}_{2} \mathrm{HPO}_{4}$, the $\mathrm{pH}$ of the magnesia-silica fume slurry decreased over time, from 10.9 to 9.4 after a week, as shown in Fig. 1. The $\mathrm{pH}$ measured at the third hour of stirring was considered as the initial $\mathrm{pH}$. The slope of the trendline is -0.30 . A high initial $\mathrm{pH}$ indicates the dissolution of magnesia as follows:

$$
\mathrm{MgO}(s)+\mathrm{H}_{2} \mathrm{O}(l) \rightarrow \mathrm{Mg}^{2+}(a q)+2 \mathrm{OH}^{-}(a q)
$$

On the other hand, the $\mathrm{pH}$ reduction indicates the reaction between silica and $\mathrm{OH}^{-}$, as proposed by Seidel et al. [8]:

$$
\mathrm{SiO}_{2}(s)+2 \mathrm{OH}^{-}(a q) \rightarrow \mathrm{SiO}_{2}(\mathrm{OH})_{2}^{2-}(a q)
$$

The formation of MSH gel could be explained by the reaction below:

$\mathrm{Mg}^{2+}(a q)+\mathrm{SiO}_{2}(\mathrm{OH})_{2}{ }^{2-}(a q)+\mathrm{H}_{2} \mathrm{O}(l) \rightarrow \mathrm{MSH}(a q)$

Disodium hydrogen phosphate $\left(\mathrm{Na}_{2} \mathrm{HPO}_{4}\right)$ caused an increase in the initial $\mathrm{pH}$ of the slurry:[7]

$$
\begin{aligned}
2 \mathrm{NaH}_{2} \mathrm{PO}_{4}(a q)+ & \mathrm{MgO}(s)+\mathrm{H}_{2} \mathrm{O}(l) \rightarrow \\
& \operatorname{Mg}\left(\mathrm{H}_{2} \mathrm{PO}_{4}\right)_{2}(a q)+2 \mathrm{NaOH}(a q)
\end{aligned}
$$

The initial $\mathrm{pH}$ stayed constant at $11.8-11.9$ when the concentration of $\mathrm{Na}_{2} \mathrm{HPO}_{4}$ increased from 5 to 10 and $18 \mathrm{wt} \%$ while the slopes of trendlines increased from -0.39 to -0.31 and -0.27 , respectively. Although the $\mathrm{pH}$ of phosphate-added slurry decreased, it was always higher than that of the non-phosphate added one at the same time of measurement. This observation indicates that $\mathrm{Na}_{2} \mathrm{HPO}_{4}$ does affect the kinetics of MSH formation by providing additional hydroxyl groups for the hydration of silica. However, its effectiveness is substantial only at small amounts of addition.

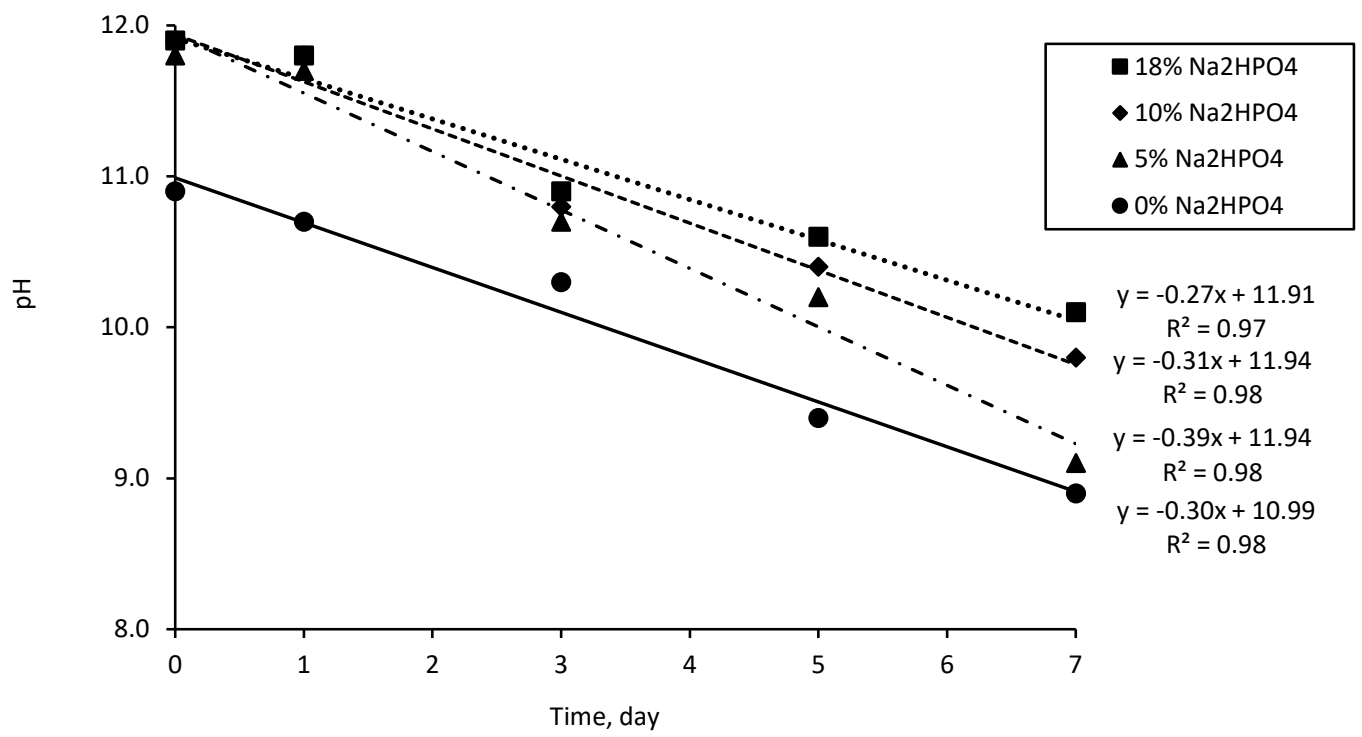

Fig. 1. The $\mathrm{pH}$ of magnesia - silica fume slurries over seven days at $22^{\circ} \mathrm{C}$. 


\subsection{Effects of Heating on the pH of Magnesia-Silica Fume Slurry.}

The plots of $\mathrm{pH}$ versus time can be divided into two stages, namely, $\mathrm{pH}$ increasing and $\mathrm{pH}$ decreasing (Fig. 2). The increase of $\mathrm{pH}$ in the first two or three hours is attributed to the domination of $\mathrm{MgO}$ dissolution. Later, $\mathrm{OH}$ - ions were consumed by silica, followed by a reduction of the $\mathrm{pH}$. This phenomenon was observed in all three heating conditions, $30^{\circ} \mathrm{C}$, $40{ }^{\circ} \mathrm{C}$ and $50{ }^{\circ} \mathrm{C}$. For the slurries hot stirred at $30^{\circ} \mathrm{C}$, the $\mathrm{pH}$ curve reaches its maximum after 210 minutes, whereas the ones heated at $40^{\circ} \mathrm{C}$ and $50^{\circ} \mathrm{C}$ reach their peaks after 195 minutes and 135 minutes, respectively.

Noticeably, the $\mathrm{pH}$ of the one hot stirred at $50^{\circ} \mathrm{C}$ was reduced to 8.9 after 270 minutes, equal to that of the one stirred at $22{ }^{\circ} \mathrm{C}$ after seven days. This observation implies that the dissolution of $\mathrm{SiO}_{2}$ was activated at an early moment upon hot mixing, followed by MSH formation, and hindered the continual hydration reaction of $\mathrm{MgO}$. This mechanism is beneficial to the protection of magnesia aggregates in basic refractory castables.

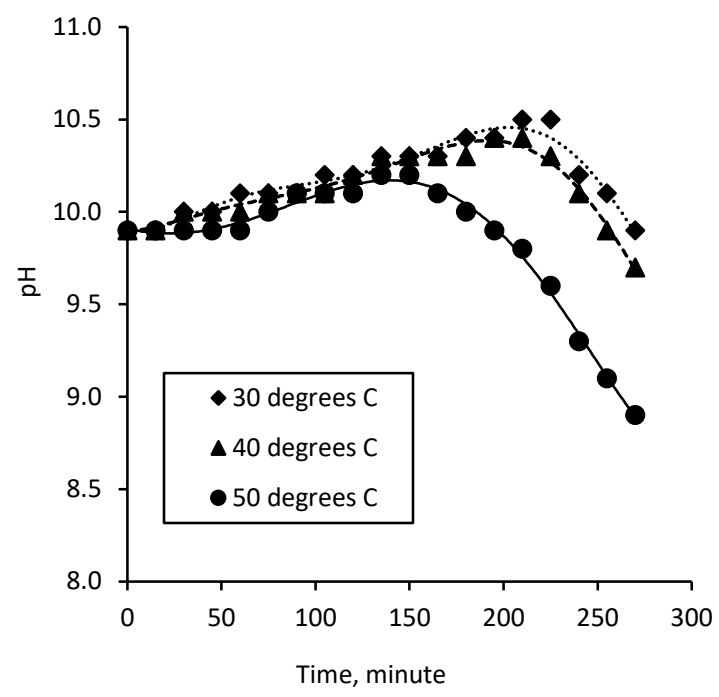

Fig. 2. Effects of temperature on the $\mathrm{pH}$ of magnesiasilica fume slurries.

\subsection{Dehydration of MSH.}

Fig. 3 shows the thermogravimetric analysis (TG/DTG) of wet filtride obtained from the slurry stirred at $50{ }^{\circ} \mathrm{C}$. Weight loss occurred at the very beginning of the heating process, reached a maximum rate of $17.7 \% / \mathrm{min}$ at $140{ }^{\circ} \mathrm{C}$, and almost finished at $200^{\circ} \mathrm{C}$. This weight loss is attributed to free water and structural water in the wet gel. The content of these two types of water is approximately $66 \mathrm{wt} \%$. Due to rapid heating, $10^{\circ} \mathrm{C} / \mathrm{min}$, water vapor was continuously swept away, making the gel unable to crystallize. Hence, it is impossible to distinguish the evaporation of the two types of water on the basis of a thermometric analysis.

In reality, the presence of free water might cause an explosion due to high internal pressure as a result of free water evaporation. Therefore, after molding, refractory castables often undergo slow drying, followed by gradual heating before running at their full capacity [3]. Regarding this fact, measuring weight loss after drying the wet gel would help to understand the kinetics of dry gel dehydration.

Fig. 4 presents the dehydration of the dry gel. The weight of the dried sample fired at $1000{ }^{\circ} \mathrm{C}$ was taken as the reference. The weight difference between the fired samples and the reference was taken as the structural water. Two steep slopes are presented. The first one is in the range from $300{ }^{\circ} \mathrm{C}$ to $450{ }^{\circ} \mathrm{C}$, and the second one is in the range from $550{ }^{\circ} \mathrm{C}$ to $600{ }^{\circ} \mathrm{C}$, indicating the dehydration of different hydrate products. These hydrate products are presented on the X-ray diffraction pattern of the gel fired at $350{ }^{\circ} \mathrm{C}$ in Fig. 5.

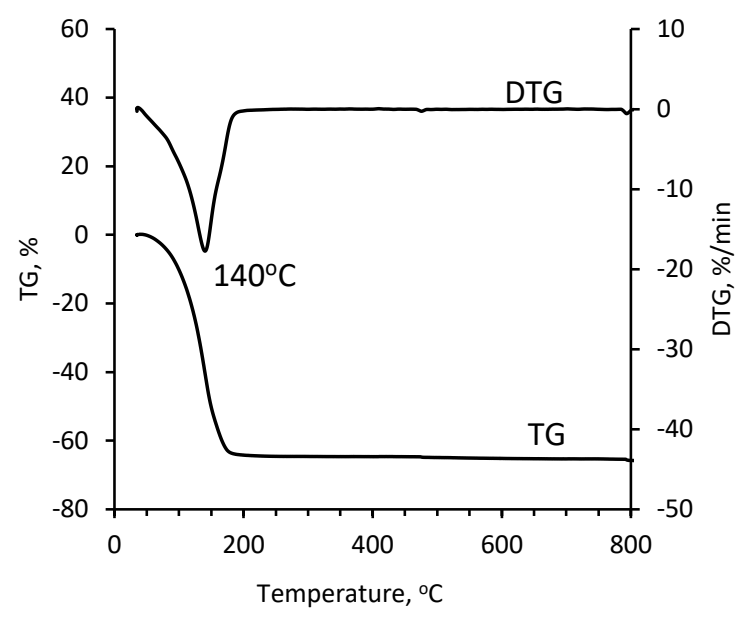

Fig. 3. Thermogravimetric analysis of the filtride.

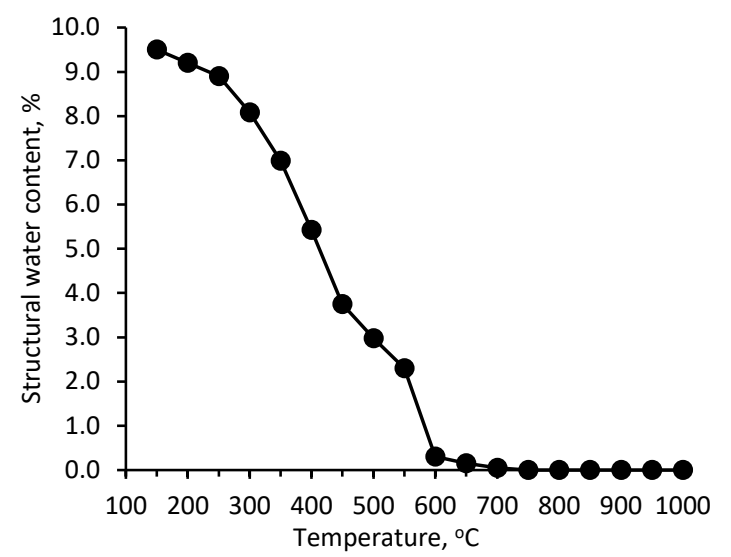

Fig. 4. Structural water loss of the dried filtride upon heat treatment. 


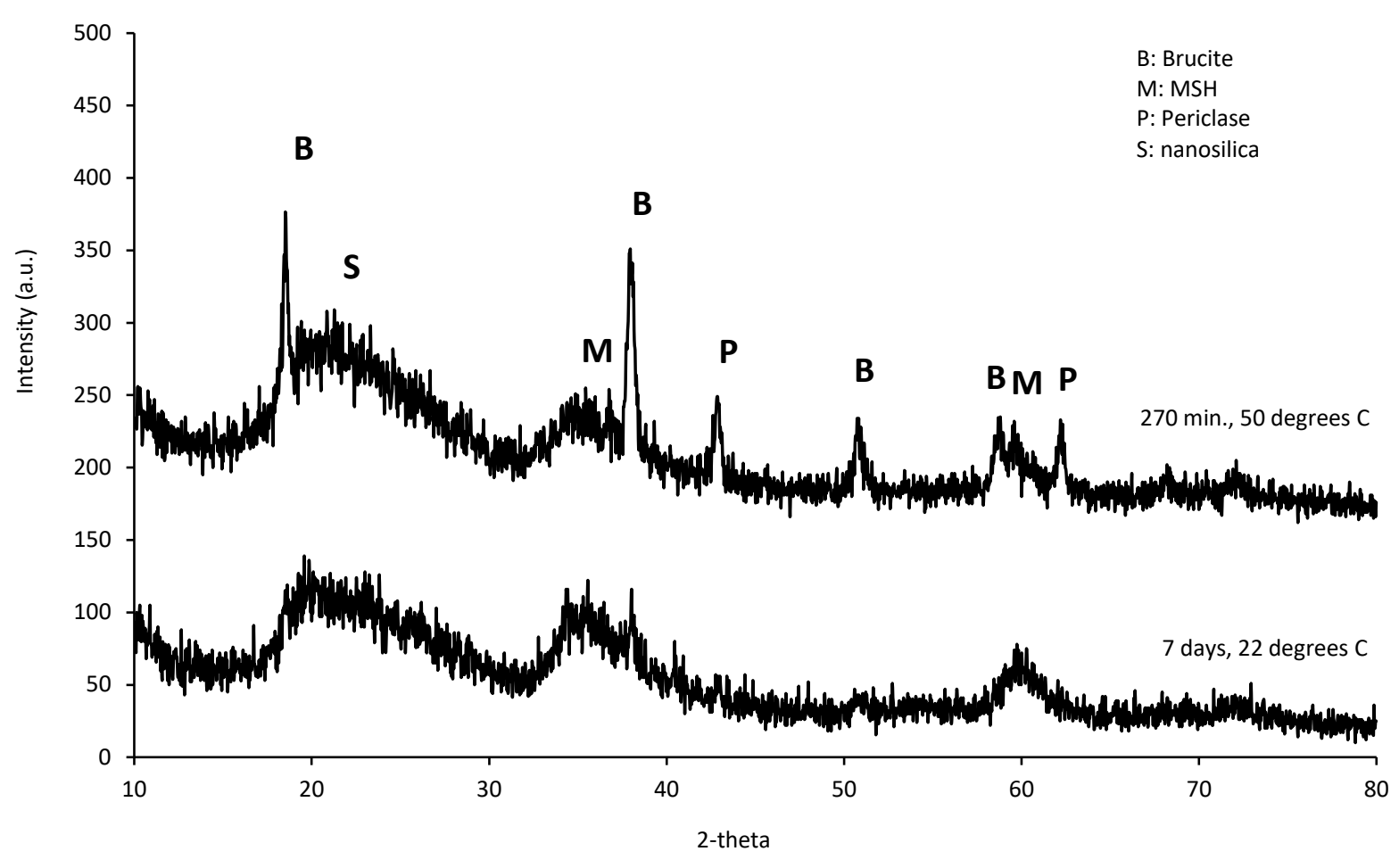

Fig. 5. X-ray diffraction patterns of filtrides after curing at $350^{\circ} \mathrm{C}$ in two hours.

Three broad low-intensity diffraction peaks were observed on the filtride obtained after seven days of stirring at $22{ }^{\circ} \mathrm{C}$ and underwent two hours cured at $350{ }^{\circ} \mathrm{C}$. The first peak at 2-theta of 22 degrees comes from the amorphous silica [9], indicating an exceeded addition of silica fume in the initially prepared slurry. The other two peaks at 2-theta of 36 degrees and 60 degrees come from dried MSH, as suggested by Wailling et al. [10]. Faint peaks of the brucite $\left(\mathrm{Mg}(\mathrm{OH})_{2}\right.$ appear at 2-theta of 18.8 degrees and 38 degrees. The first two mentioned peaks confirm the formation of $\mathrm{MSH}$ and the later indicates a partial decomposition of MSH to form brucite as follows:

$$
\mathrm{MSH} \rightarrow \mathrm{Mg}(\mathrm{OH})_{2}(s)+\mathrm{SiO}_{2}(s)+\mathrm{H}_{2} \mathrm{O}(g)
$$

Brucite could come from magnesium hydroxide as well:

$$
\mathrm{Mg}(\mathrm{OH})_{2}(a q) \rightarrow \operatorname{Mg}(\mathrm{OH})_{2}(s)
$$

For the filtride obtained after 270 minutes of stirring at $50{ }^{\circ} \mathrm{C}$ and underwent two hours cured at $350{ }^{\circ} \mathrm{C}$, silica fume was again not consumed completely. The presence of intense brucite and periclase $(\mathrm{MgO})$ diffraction peaks proves that more MSH was formed during hot stirring than in the other case. The decomposition of MSH underwent two steps, forming brucite as mentioned above and forming periclase as follows:

$$
\mathrm{Mg}(\mathrm{OH})_{2}(s) \rightarrow \mathrm{MgO}(s)+\mathrm{H}_{2} \mathrm{O}(g)
$$

In both cases, the diffraction peaks of talc, a possible intermediate product of MSH gel dehydration, do not appear.

Too much water is undesirable in the construction of refractory castables since the evaporation of excess water during drying leaves behind structural pores that cause low compressive strength for the material. In practice, refractory castables are mixed with just enough water to produce bonding gel and flow smoothly. The early formation of MSH gel is advantageous in two aspects, namely bonding and protecting the aggregates. The differences in the amount of MSH product between hot stirring and cold stirring remained unanswered in this work. A further study on that topic is worth doing.

\section{Conclusion}

The results suggest that both $\mathrm{Na}_{2} \mathrm{HPO}_{4}$ addition and hot mixing affect the promote the formation of MSH gel. However, $\mathrm{Na}_{2} \mathrm{HPO}_{4}$ showed a weaker impact even after seven days of stirring. On the other hand, hot stirring at $50{ }^{\circ} \mathrm{C}$ caused a significant reduction of the $\mathrm{pH}$ of the magnesia - silica fume slurry, indicating a substantial consumption of $\mathrm{OH}^{-}$for MSH formation. In reality, most of the time, refractory castables are mixed and cast outdoor where the ambient temperature can be as high as $50{ }^{\circ} \mathrm{C}$ in tropical countries like Vietnam. Even in the winter, mixing at $50{ }^{\circ} \mathrm{C}$ is feasible with the use of hot water. Thus, it is worth applying this work's observation to study the effects of hot mixing on real refractory mixtures. 


\section{Acknowledgments}

This work was funded by Hanoi University of Science and Technology under the grand number T2018-PC-099.

\section{References}

[1] A. Kitamura, The hydration characteristics of magnesia, Taikabutsu, vol. 48, (1996) 112-122.

[2] D. A. Vermilyea, The dissolution of $\mathrm{MgO}$ and $\mathrm{Mg}(\mathrm{OH})_{2}$ in aqueous solutions, Journal of the Electrochemical Society, vol. 116, no. 9, (1969) 11791183.

https://doi.org/10.1149/1.2412273

[3] R. Salomão and V. C. Pandolfelli, Microsilica addition as an antihydration technique for magnesia-containing refractory castables, American Ceramic Society Bulletin, vol. 86, no. 6, (2007) 9301-9306.

[4] L. Amaral, I. Oliveira, P. Bonadia, R. Salomão, and V. Pandolfelli, Chelants to inhibit magnesia (MgO) hydration, Ceramics International, vol. 37, no. 5, (2011) 1537-1542.

https://doi.org/10.1016/j.ceramint.2011.01.030

[5] T. Souza et al., Phosphate chemical binder as an antihydration additive for $\mathrm{Al}_{2} \mathrm{O}_{3} .3 \mathrm{MgO}$ refractory castables, Ceramics International, vol. 40, no. 1 , (2014) 1503-1512.

https://doi.org/10.1016/j.ceramint.2013.07.035
[6] I.-H. Jung, S. A. Decterov, and A. D. Pelton, Critical thermodynamic evaluation and optimization of the $\mathrm{CaO}-\mathrm{MgO}-\mathrm{SiO}_{2}$ system, Journal of the European Ceramic Society, vol. 25, no. 4, (2005) 313-333. https://doi.org/10.1016/j.jeurceramsoc.2004.02.012

[7] V. Chernyakhovskii, Technology of unfired periclasespinel parts with a phosphate binder, Refractories, vol. 26, no. 1-2, (1985) 41-44. https://doi.org/10.1007/BF01398613

[8] H. Seidel, L. Csepregi, A. Heuberger, and H. Baumgärtel, Anisotropic etching of crystalline silicon in alkaline solutions: I. Orientation dependence and behavior of passivation layers, Journal of the Electrochemical Society, vol. 137, no. 11, (1990) 3612-3626. https://doi.org/10.1149/1.2086277

[9] E. Prud'homme et al., Silica fume as porogent agent in geo-materials at low temperature, Journal of the European Ceramic Society, vol. 30, no. 7, (2010) 1641-1648.

https://doi.org/10.1016/j.jeurceramsoc.2010.01.014

[10] S. A. Walling, H. Kinoshita, S. A. Bernal, N. C. Collier, and J. L. Provis, Structure and properties of binder gels formed in the system $\mathrm{Mg}(\mathrm{OH})_{2}-\mathrm{SiO}_{2}-\mathrm{H}_{2} \mathrm{O}$ for immobilisation of Magnox sludge, Dalton Transactions, vol. 44, no. 17, (2015) 8126-8137. https://doi.org/10.1039/C5DT00877H 